American Journal of Applied Sciences 4 (8): 547-553, 2007

ISSN 1546-9239

(C) 2007 Science Publications

\title{
The Provenance of the Varzaneh Aeolian Sand Field Regarding to Lithology and Texture, SW Esfahan, Iran
}

\author{
Pakzad, H. and Ajalloeian, R. \\ Department of Geology, Faculty of Sciences, Esfahan University, 81746-72441, Esfahan, Iran
}

\begin{abstract}
The main mineralogical/lithological composition of the Varzaneh aeolian sands is sedimentary and igneous lithics. The minor one is metamorphic lithics and mineral grains (such as quartz, feldspar and heavy mineral grains) respectively. The origin of the sedimentary lithics (mainly carbonates) mostly is from sedimentary rocks exposed in the west and the southwest of the study area. These rocks belong to Cretaceous and Jurassic outcrops. The origin of the igneous lithic grains chiefly belongs to Tertiary highlands, located to the north and the northeast of the study area. The main origin of the metamorphic lithic grains is from the mountain ranges located in the north-western and the western part of the drainage basin of the Zayandeh river. Texture of the aeolian sand grains is similar to the Zayandeh river sediments. Concentration of the aeolian sands at the west of the Zayandeh river delta, variation of their mineralogical/lithological composition from north to south, and textural characterizations of sand grains indicate that the water laid sediments of the Zayandeh river, widespread to the north of the aeolian sands, are the main supply of the aeolian sands and sediments deposited by the two ephemeral streams in the south and the southwest of the sand dunes are minor one.
\end{abstract}

Key words: aeolian sand, lithic grains, mineralogical composition, texture, sediments

\section{INTRODUCTION}

The term provenance, in general, refers to a location of origin, where the sediments are derived from, and the nature of source rocks ${ }^{[2]}$. In provenance studies, however, it is used in a wider sense including all the factors, which influence the production and composition of sediments. These are chiefly the nature of source rocks, their position relative to deposition site and the pathways by which sediments are transferred from source to depositional basin. The mineralogical/lithological composition of aeolian sands is a powerful indicator for determination of provenance of the components, but also for recognition of the tectonic setting of the source area, weathering and paleo climate history ${ }^{[4]}$. Since the provenance determination is a main objective of this paper, detailed description of this aspect is necessary.

Regional setting: The Varzaneh aeolian sand field is located in an intramontane basin in central Iran, which is well developed parallel to the Zagros orogenic belt ${ }^{[1]}$. This structural basin is as a supposed graben or halfgraben system resulted from orogenic movements, volcanic eruptions at the end of Cretaceous and Early Eocene, and faulting which took place after the volcanism in some central parts of Iran, and also in the study area ${ }^{[3,7]}$.

It occurs in the southeast of Esfahan, with an area of approximately $140 \mathrm{~km} 2,45 \mathrm{~km}$ long and maximum width of about $11 \mathrm{~km}$ in the north. Two main subenvironments can be differentiated in the study area: sand dunes and sand sheets. The Gavkhoni playa lake extends with an area of about $550 \mathrm{~km} 2$ to the east of this field. The Zayandeh river, which is a permanent river, runs from the north of this area and enters finally into the Gavkhoni playa lake. Coarse-grained alluvial deposits border the aeolian sand field in the west, and the south (Fig. 1). The land surface is of low relief with a maximum height of $1607 \mathrm{~m}$ (north of aeolian sand dunes) and a minimum of $1474 \mathrm{~m}$ (Gavkhoni playa lake) above sea level. Varzaneh has a dry and hot climate with annual precipitation and evaporation average of about 80 and $3265 \mathrm{~mm}$ respectively. The annual average temperature ranges between $+420 \mathrm{C}$ (July) and $-17 \mathrm{oC}$ (January). Wind blows from all directions but westerly winds dominate throughout the year $^{[5,6]}$.

\section{MATERIALS AND METHOD}

In order to achieve the objectives, field and laboratory works were carried out to get required data. Using Land sat TM image, sub-environments of the aeolian sand field and location of sampling were determined (Figs. $1 \& 2$ ). About 60 representative samples (sand fraction) were selected for analysis of heavy minerals. Thin sections of about 90 samples were prepared $(0-1,1-2$ and 2-3 phi fractions) for determination of lithic and mineral grains. Carbonate content of about 40 samples (sand fraction) was undertaken using a chemistry method. Surface texture of about 20 samples of alluvial and aeolian sand grains were examined by SEM.

\footnotetext{
Corresponding Author: $\quad$ Ajalloeian, R. Department of Geology, Faculty of Sciences, Esfahan University, 81746-72441, Esfahan, Iran
} 


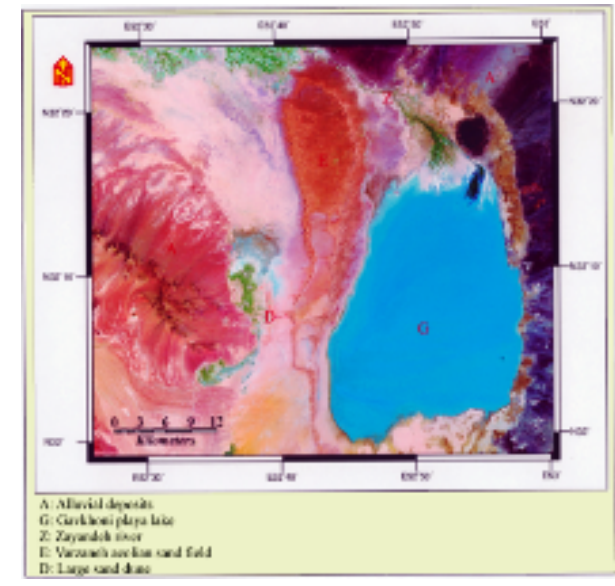

Fig: 1: False color-Land sat TM image of the Varzaneh aeolian sand field and its surrounding depositional environments.

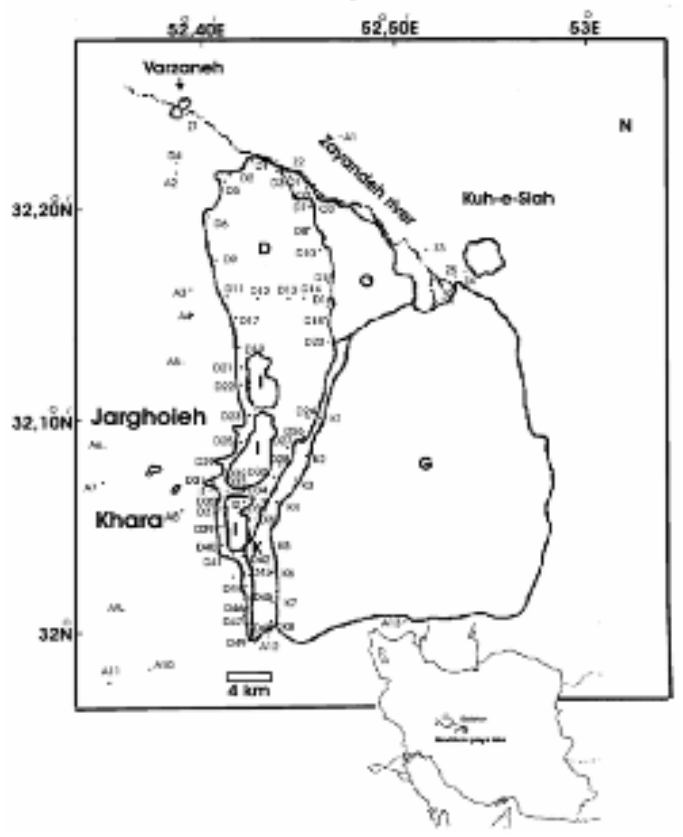

Fig. 2: Simplified map showing approximate locations of sampling, in the study area. D (sand dune), G (Gavkhoni playa lake), I (interdune sand sheet), O (over bank sand sheet), K (sabkha sand sheet).

Mineralogical/lithological composition of grains:

Lithic grains: Lithic grains are the most abundant grains in the studied samples and usually decrease in frequency according to decrease in grain size.

Three main types of lithics including igneous, sedimentary and metamorphic grains are found in the studied sand grains (see Fig. 9). The average frequency percentage of the lithic grains and mineral grains in the representative samples are presented in Table 1 and Fig. 3.

Igneous lithics: Igneous lithics consist of dacite, andesite, acidic tuff, diorite, granite, microgranite and a subordinate amount of andesite-basalt and basalt grains in the studied samples. The average frequency percentage of the igneous lithics is about $37 \%$ in the aeolian sands (see Table 1). Their content decreases in frequency from north to south. Exceptionally, the amount of igneous lithic increases slightly at the end southern part of the aeolian sand field (Fig. 4).

Sedimentary lithics: Sedimentary lithics mostly consist of carbonates and few sandstones, siltstones, shales and chert grains. The average frequency percentage of the sedimentary lithic grains in the aeolian sand samples is about $52 \%$ (approximately $49 \%$ carbonate and $3 \%$ noncarbonate). The carbonate content of representative samples determined by chemical analysis ranges in turn from about $17 \%$ and $79 \%$ in aeolian and alluvial samples (Fig. 5).

Sedimentary lithics The Carbonate lithic grains include micrit, sparite, biosparite, biomicrite and crystalline carbonate. Shell fragments are mostly composed of foraminifera (Orbitolina, Orbitoides, Heterastegina, miliolids), ostracods, gastropods (mainly Bithynia phialensis), algae (red and green) and rudists. Orbitolina belongs to Aptian, Orbitoides to Campanian-Maastrichtian, algae and rudists mostly Aptian to Maastrichtian, Heterastegina to OligoMiocene, gastropods and ostracods to Quaternary. According to the palaeontological studies, the carbonate grains come mostly from Cretaceous rocks, and subordinate amounts from Tertiary rocks (OligoMiocene).

The relative frequency of sedimentary lithics (carbonates), in contrast to the igneous lithics, increases from north to south of the aeolian sand field, expect that they decrease slightly at the end of the southern part of the sand dunes (see Figs. $4 \& 5$ ).

Metamorphic lithics: Metamorphic lithics mostly consist of schist (chlorite, muscovite, biotite, and quartz schist), and subordinate amount of quartzite, gneiss, amphibolite schist, actinolite schist, and metagranite grains. The average frequency percentage of the metamorphic lithics is about $1.5 \%$ (seeTable 1) in the aeolian sands. The percentage of these grains decreases from north to south within the aeolian sands (Fig. 6). 
Table 1: Frequency percentage of lithic and mineral grains of alluvial and aeolian sediments in the 31 representitive samples in the study area. Alluvial sediments (samples. A and Z) and aeolian sands (samples. D, I and K) (see Fig. 2 for position of samples ). Igneous lithic (I), sedimentary lithic (S), metamorphic lithic (M), quartz (Q), feldspar (F), and gypsum (G)

\begin{tabular}{|c|c|c|c|c|c|c|c|c|c|c|c|c|c|}
\hline & Samples & A1 & A2 & $\mathbf{A 3}$ & A5 & A6 & A7 & A9 & A10 & A11 & A13 & D1 & D3 \\
\hline$I$ & & 39 & 50 & 72 & 52 & 10 & 11 & 3 & 4 & 16 & 41.5 & 55 & 44.5 \\
\hline$S$ & & 39 & 32 & 18 & 37 & 70 & 74 & 95 & 93 & 72 & 51 & 30 & 39.7 \\
\hline$M$ & & 11 & 5 & 2 & 4 & 0 & 1 & 0 & 0 & 0 & 0 & 3.5 & 3 \\
\hline$Q$ & & 8 & 9.5 & 6 & 3 & 15 & 10 & 2 & 1.5 & 11 & 7 & 10 & 11 \\
\hline$F$ & & 3 & 3.5 & 2 & 1 & 5 & 4 & 0 & 1.5 & 1 & 0.5 & 1.5 & 0.8 \\
\hline$G$ & & 0 & 0 & 0 & 0 & 0 & 0 & 0 & 0 & 0 & 0 & 0 & 0 \\
\hline & Samples & D7 & D11 & D13 & D15 & D16 & D21 & D27 & D28 & D30 & D32 & D35 & D43 \\
\hline$I$ & & 64 & 26 & 38 & 58.5 & 54 & 31 & 40 & 45 & 31 & 27 & 23 & 27 \\
\hline$S$ & & 22.5 & 63 & 45 & 21 & 30 & 59 & 48.5 & 31 & 36 & 55 & 69 & 68 \\
\hline$M$ & & 0.5 & 1.5 & 1.5 & 2.5 & 0 & 2 & 0.5 & 4 & 0.5 & 2 & 1 & 1 \\
\hline$Q$ & & 12 & 8 & 13.5 & 15 & 15 & 7 & 9 & 15 & 11 & 15 & 6 & 4 \\
\hline$F$ & & 1 & 1.5 & 2 & 3 & 1 & 1 & 1 & 5 & 0.8 & 1 & 1 & 0 \\
\hline$G$ & & 0 & 0 & 0 & 0 & 0 & 0 & 1 & 0 & 0.7 & 1 & 0 & 0 \\
\hline
\end{tabular}

\begin{tabular}{llllllll}
\hline $\begin{array}{r}\text { Sample } \\
\text { No }\end{array}$ & D44 & D46 & I1 & K1 & K2 & Z1 & Z5 \\
Lithology & & & & & & & \\
\hline $\boldsymbol{I}$ & 28 & 31 & 29 & 33 & 23 & 36 & 54 \\
$\boldsymbol{S}$ & 59 & 57 & 60 & 59.5 & 63 & 37 & 32 \\
$\boldsymbol{M}$ & 1.5 & 0 & 1.5 & 0.5 & 1.5 & 25 & 5 \\
$\boldsymbol{Q}$ & 9 & 10 & 7 & 5 & 9 & 1 & 8 \\
$\boldsymbol{F}$ & 2.5 & 1.5 & 2 & 1.5 & 0.8 & 1 & 1 \\
$\boldsymbol{G}$ & 0 & 0 & 0.5 & 0.5 & 1.5 & 0 & 0
\end{tabular}

Mineral grains: Quartz grains are the most common mineral type in the sand size fraction (0-3 phi fractions) of the aeolian sands, ranging from $2 \%$ to up to $15 \%$ with an average of $10 \%$ (see Table $1 \&$ Fig. 7). They usually increase in frequency with decrease in grain size and therefore, are more abundant in the finegrained sand fraction, in contrast to igneous and sedimentary lithics. Quartz grains frequency is rather irregular in the sand dunes from the north to the south (Fig. 7).

Feldspar: Feldspar grains are the third common mineral type in the sand size fraction of the aeolian sands. Average frequency of the feldspar grains is about $1.5 \%$ (see Table 1 \& Fig. 7). Distribution of the feldspar grains is irregular in the sand dunes similar that of quartz grains (Fig. 7). They are represented mainly by plagioclase (albite to oligoclase and andesine) with subordinate amounts of potash feldspar (microcline and orthose). The occurring major types of the feldspar grains are similar to that the intermediate and acidic volcanic igneous rocks, exposed in the northeast of the study area.

Heavy minerals: Heavy mineral grains are the second common minerals in the fine and very fine sand fractions of the aeolian and alluvial sediments in the study area. The average frequency percentage of the heavy minerals ranges from $2 \%$ to $3 \%$ in the fine to very fine sand fractions of the aeolian sands. Overall, the frequency percentage of the heavy minerals decreases from north to south of the Varzaneh aeolian sand field (Fig. $8 \&$ Table 2). The occurring heavy minerals are mainly garnet, pyroxene, hematite, and, subordinately amphibole, epidote, limonite, zircon, rutile and magnetite. Mica, apatite, scheelite, pyrite (oxidized), barite, sphene, ilmenite, jarosite, glauconite, chlorite, leucoxene and celectine are also observed in traces. 
Am. J. Applied Sci., 4 (8): 547-553, 2007

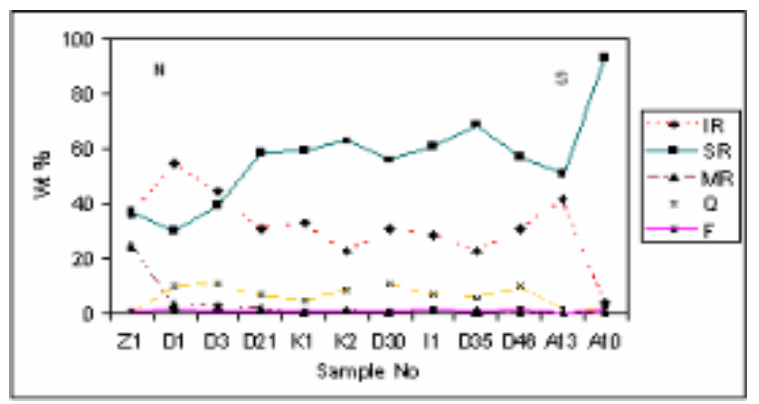

Fig. 3: Distribution of the various types of grains in the representative samples of aeolian sands (samples D, K \& I) and alluvial sediments (sample A) in the study area. Igneous lithic (IR), sedimentary lithic (SR), metamorphic lithic (MR), quartz (Q), feldspar (F) (see Fig. 2 for position of samples No). N(north), S(south)
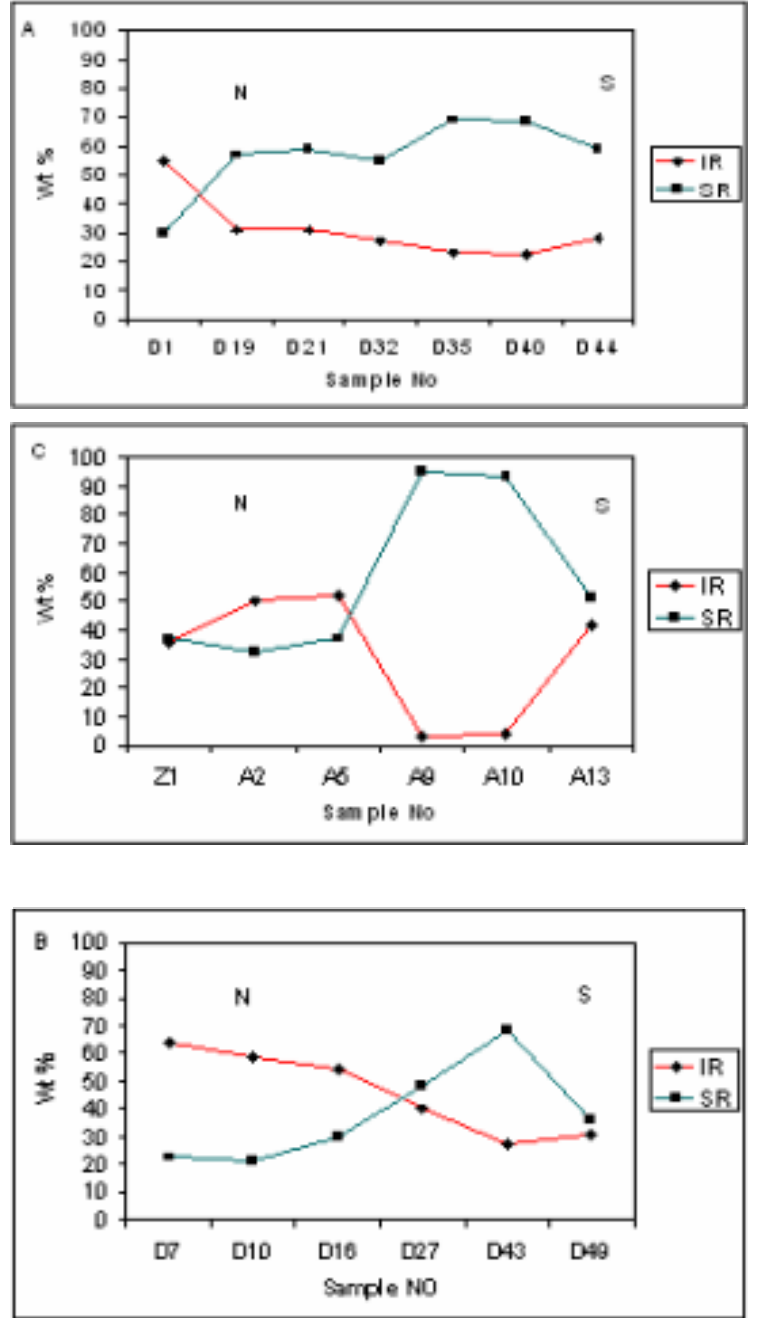

Fig. 4: Distribution of igneous and sedimentary lithic grains in the western (A) and the eastern (B) parts of the Varzaneh sand dunes and $(C)$ in alluvial sediments from north to south of the study area. Igneous lithic (IR) and sedimentary lithic (SR) (see Fig. 2 for position of samples ). N (north), S (south).
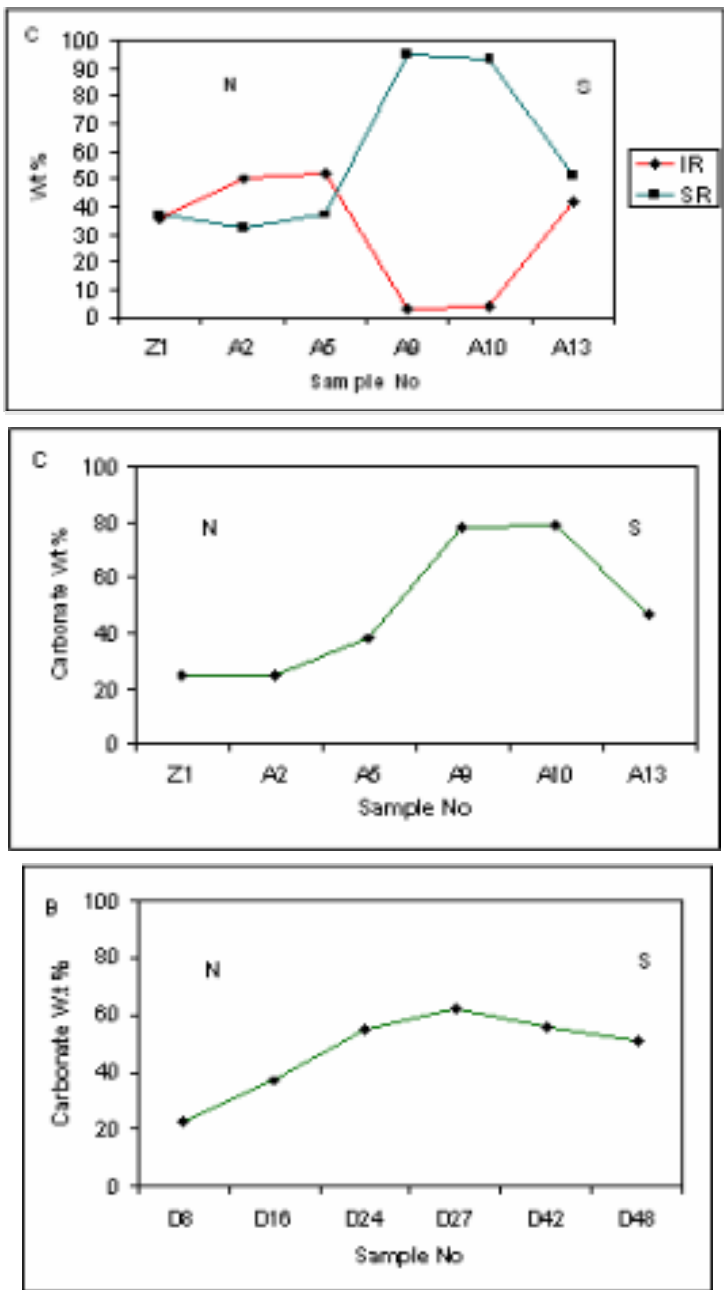

Fig. 5: Variations of frequency percentage of carbonate lithics in the western (A), the eastern (B) parts of the Varzaneh sand dunes and (C) alluvial sediments from north to south of the study area (see Fig. 2 for position of samples ). N (north), S (south)

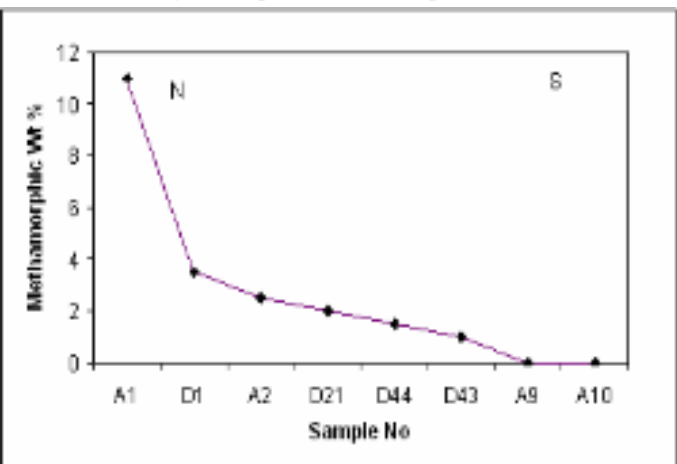

Fig . 6: Distribution of metamorphic lithic grains in the representative samples of alluvial sediments (sample. A) and aeolian sands (sample. D) (see Fig. 2 for position of samples No). N (north), S (south). 
Am. J. Applied Sci., 4 (8): 547-553, 2007

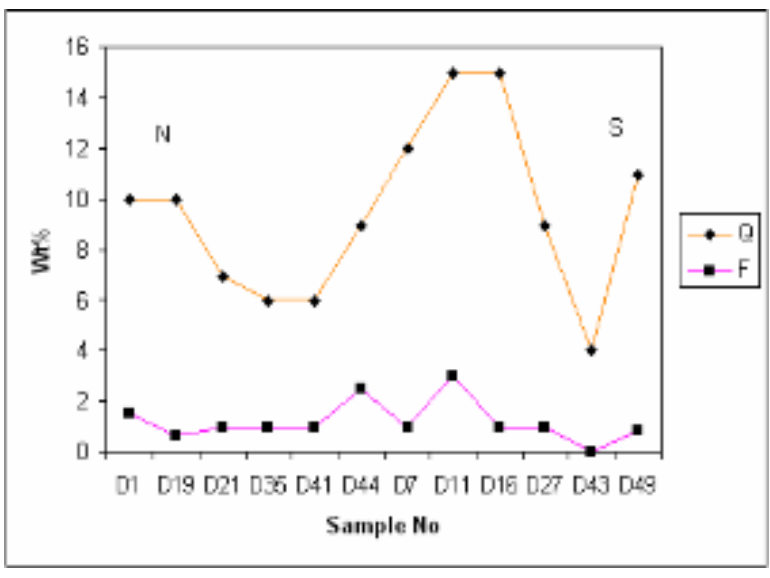

Fig. 7: Distribution of quartz and feldspar grains in the representative sand dune samples (see Fig. 2 for position of samples No). N (north), S (south).

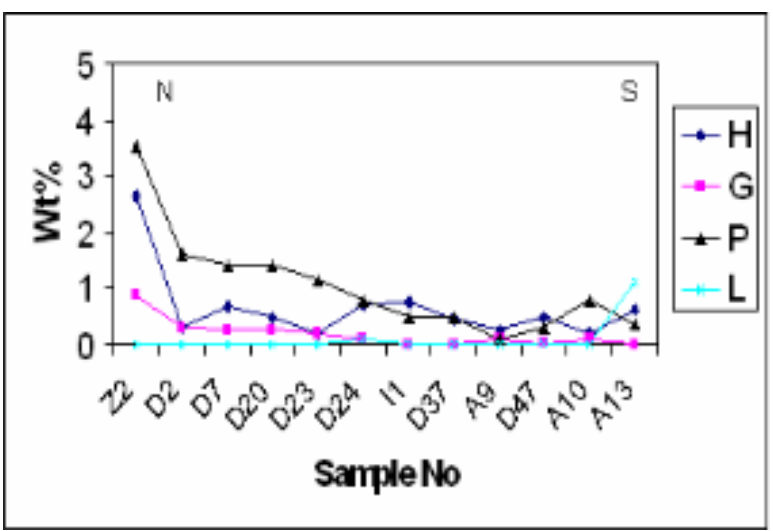

Fig. 8: Distribution of total heavy mineral grains in the representative samples of the aeolian and alluvial sediments sand fraction. Total $(T)$, hematite $(H)$, garnet $(\mathrm{G})$, pyroxene $(\mathrm{P})$, and limonite (L), N (north), S (south).

Opaque minerals comprise almost one third of the heavy mineral fraction. Hematite is the common opaque heavy mineral and its distribution is not regular from the north to the south of the aeolian sands. Garnet and pyroxene are the most abundant non-opaque heavy minerals both in fine and very fine sand. These minerals are more frequent in the very fine sands and decrease in frequency from the north to the south of the aeolian sands. Tow various kinds of garnet are present, i.e. colorless and dark, the later is more abundant. Augite and hyperstene are the most abundant pyroxene minerals. Amphibols are present as green and brown hornblende ( Fig. 9).
Roundness and surface texture of sand grains: Investigation of the various types of sand (aeolian and alluvial) shown in Fig. 10 represent that: 1-The quartz grains of the aeolian sands have a roundness class that varies from angular to sub-angular depending on size fraction and feldspar grains are mostly sub-angular. 2The carbonate lithic grains of aeolian sands are rounded to well-rounded, igneous lithics sub-angular to rounded and metamorphic lithic grains angular to rounded. 3The roundness of fluvial lithic grains is approximately similar to aeolian sand grains whereas that of debris flow carbonate lithics is angular to sub-angular. 4-The grains surface of aeolian sands displays no frosting and no small pits caused by grain impacts. The roundness of sand grains depends on size, composition and degree of maturity.

Table 2: Frequency percentage of the main heavy minerals in the representative samples of the fine to very fine sand fractions from the alluvial (sample. A) and aeolian sediments (samples. D \& I) (see Fig. 2 for position of samples).

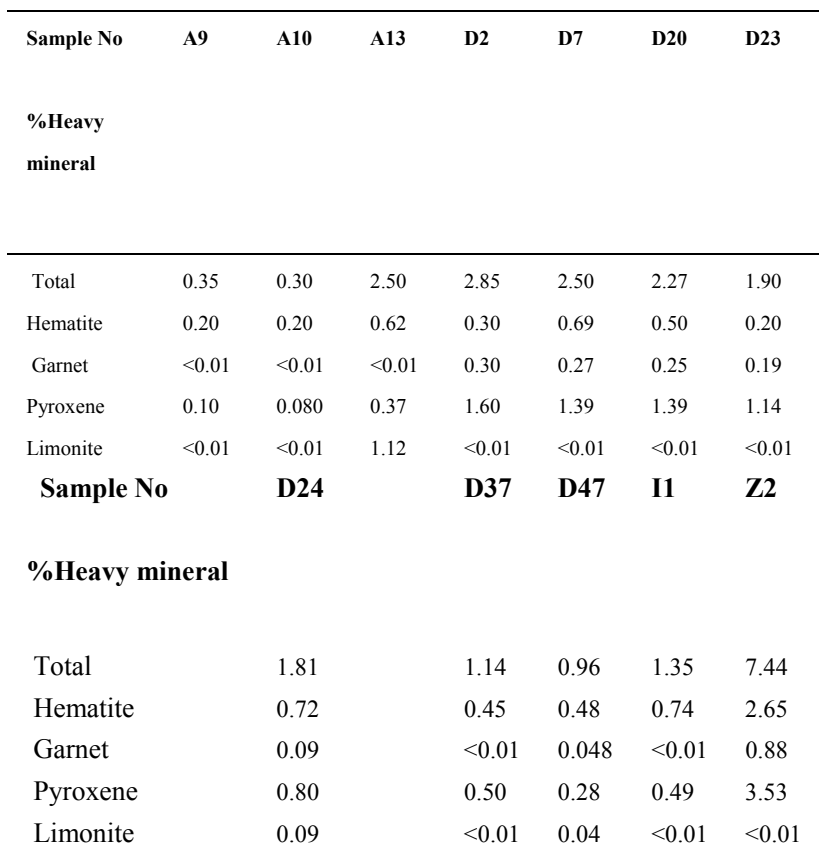


Am. J. Applied Sci., 4 (8): 547-553, 2007
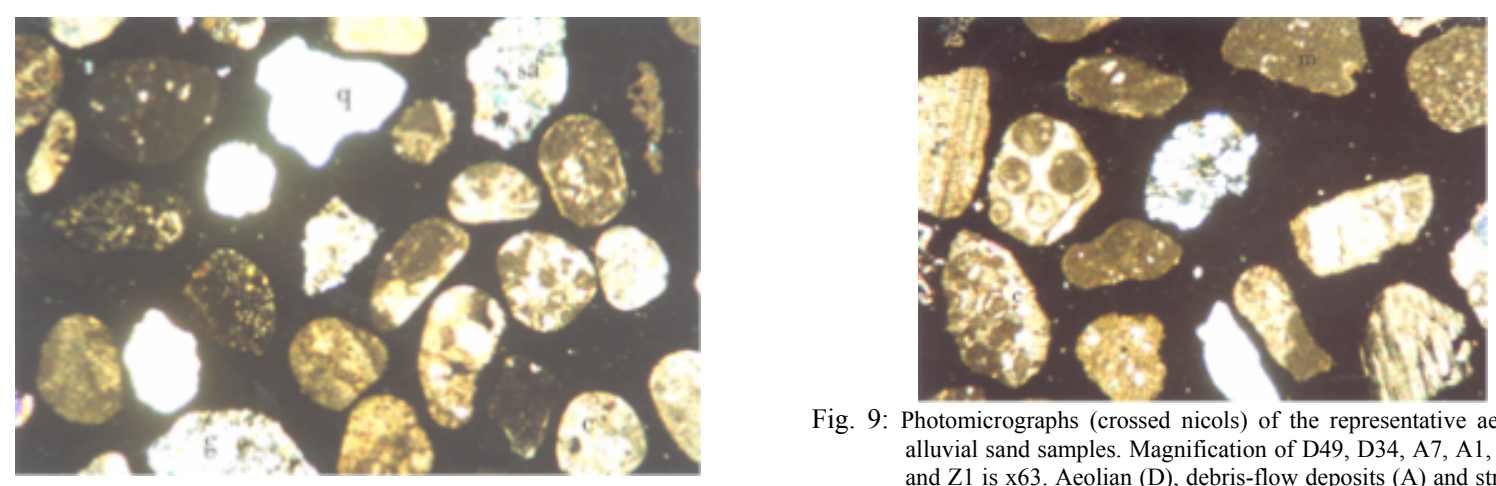

Fig. 9: Photomicrographs (crossed nicols) of the representative aeolian and alluvial sand samples. Magnification of D49, D34, A7, A1, Z3 is x23 and $\mathrm{Z1}$ is $\mathrm{x} 63$. Aeolian (D), debris-flow deposits (A) and stream-flow deposits (Z). Biomicrite (b), fossil (f), granite (g), tuff (t), carbonate (c), quartz (q), biosparite (s), mudstone (m), metagranite (mt), siltstone (si), sandstone (sa), schist (sc) (see Fig. 2 for position of samples ).
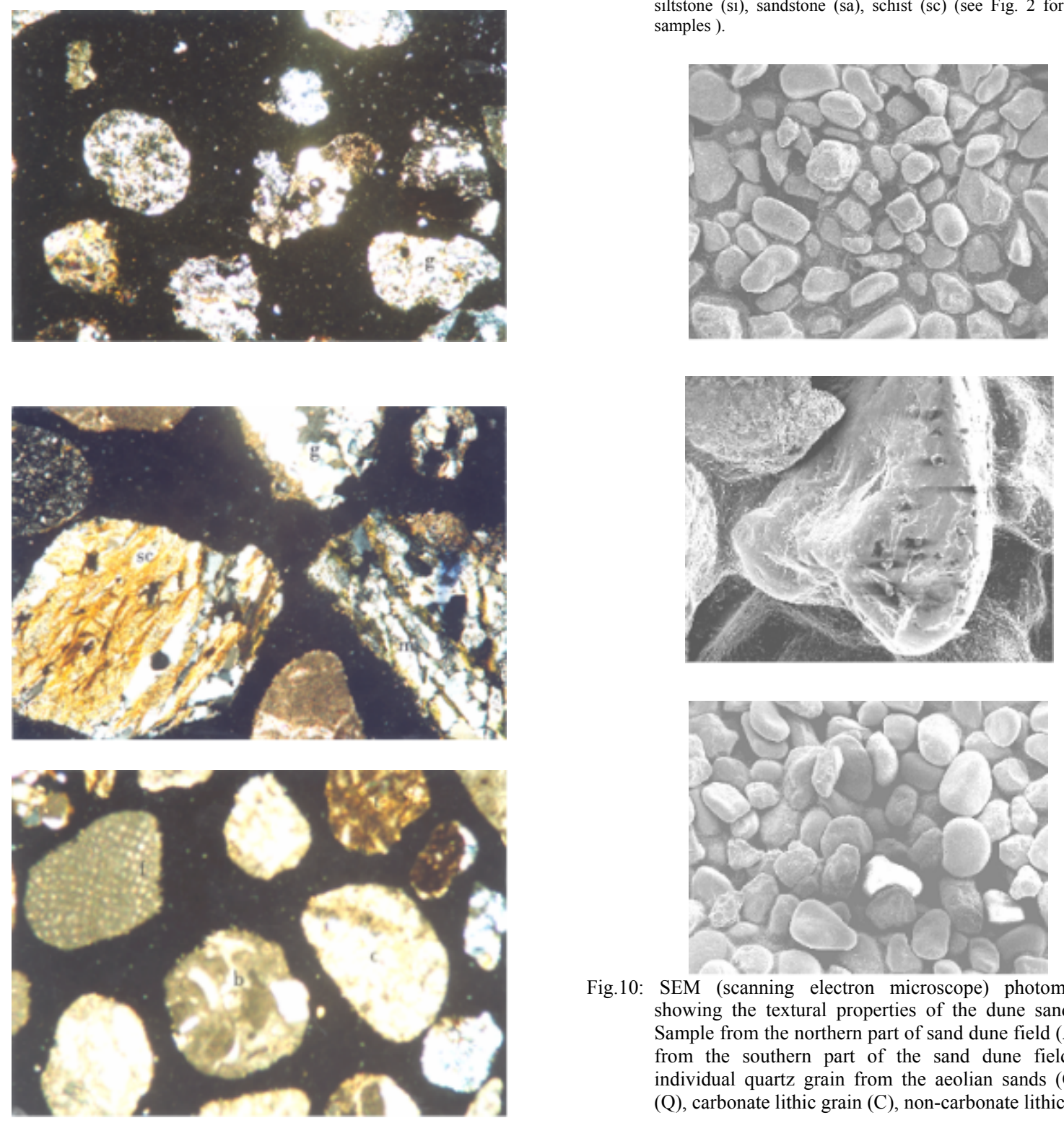

Fig.10: SEM (scanning electron microscope) photomicrographs showing the textural properties of the dune sand samples. Sample from the northern part of sand dune field (A), sample from the southern part of the sand dune field (B) and individual quartz grain from the aeolian sands (C). Quartz $(\mathrm{Q})$, carbonate lithic grain $(\mathrm{C})$, non-carbonate lithic grain $(\mathrm{N})$. 
Am. J. Applied Sci., 4 (8): 547-553, 2007

\section{DISCUSSION}

The amount of the igneous and the metamorphic lithics of the Zayandeh river sediments increases from Varzaneh toward the Zayandeh river delta. Therefore, the northern part of the aeolian sands, due to its proximity to the main source of the sand grains possesses more igneous and metamorphic lithics. The aeolian sands in the southern part of the sand dunes are mostly composed of carbonate lithics, because the south-western and southern streams consist of abundant carbonate lithics. Abnormal increase of igneous lithics at the southern end of the sand dunes is attributed to the southern streams. The irregular frequency percentage variation of quartz and feldspar is attributed to disintegration of lithics especially the igneous lithics due to their mechanical instability. The amount of the heavy minerals also decreases from north to south similar to igneous lithics cause /they are mostly derived from the Zayandeh river. The mineralogical/lithological composition of sands in the sand dunes and the interdune areas is approximately similar, because the dune sands are the source of the interdune sands, whereas mineralogical composition of sands in the over bank and the sabkha sand sheets change from north to south, because they are not only derived from dune sands but also from the fluvial sediments.

The textural properties (roundness and surface texture) of the aeolian sediments are approximately the same as in the source sediments, because the effectiveness of wind action as an abrasion agent is not the only factor in textural properties of sand grains in desert environments but also water action and proximity of aeolian ${ }_{[4]}$ ands to the source area are other important factors ${ }^{4}$.

\section{CONCLUSIONS}

Based on the mineralogical/lithological composition the aeolian sands and the alluvial sediments, igneous lithics are mostly composed of volcanic and to a minor extent of plutonic grains. They chiefly belong to Tertiary highlands, located to the north and the northeast of the study area. The major origin of the sedimentary lithics (mainly carbonates) is from sedimentary rocks exposed in the west and the southwest of the study area. These rocks belong to Cretaceous and Jurassic outcrops. The main origin of the metamorphic lithics is from the mountain ranges located in the north-western and the western part of the drainage basin of the Zayandeh river. Texture and fabric of the feldspar grains suggest that they are derived mostly from andesitic and granitic rocks. Andesitic rocks mainly outcrop in the northeast of the aeolian sands but granitic rocks are found at several locations of the drainage basin as small intrusive bodies. Garnet grains mainly are attributed to contact metamorphic rocks and pyroxenes, amphiboles, and epidotes to intermediate igneous rocks exposed in the north and the northwest of the study area. The source of zircon and rutile grains mostly could be attributed to the acidic igneous rocks outcropping in the southwest of the aeolian sands. The origin of the crystalline carbonate grains is intergranular cement from Quaternary open framework conglomeratic deposits that are exposed in the southern part of the study area. These grains were deposited mostly by the Zayandeh river to the north, and the two ephemeral streams to the south and the west margins of the aeolian sand field. Therefore major supply of the sediments in the Varzaneh aeolian sand field is the Zayandeh river sediments, concentrated northward of the aeolian sands. A minor supply is from sediments deposited by the two ephemeral streams in the south and the southwest of the sand dunes.

It is supposed that the sediment supply to the study area was mainly generated during the latest Pleistocene and earliest Holocene during humid periods of enhanced discharge by the streams. It is most probably that during interglacial dry periods, strong winds removed sand grains from the alluvium and concentrated them in the sand dune field.

\section{ACKNOWLEDGMENTS}

I would like to express my gratitude to Prof. Dr. H. Kulke for introduction to genetic sedimentologic field studies, improvement of the text, his valuable guidance at the University of Clausthal. Special thanks are given to Dr. N. Arzani from the Piam-e-Nor University for help in field studies, valuable comments, review and correction. Thanks to Dr. H. Safaei for satellite images processing. I wish to thank the technical staff of the Institute of Geology and Palaeontology of the Clausthal University for their help during laboratory works.

I am much indepted the staff of the Research Center of Nasoz-e-Azar of Esfahan (thin section) and laboratory of Geological survey of Iran (heavy minerals analysis). I would like to thank the Ministry of sciences and the University of Esfahan for financial supports.

\section{REFERENCES}

1. Alavi, M., 1994. Tectonics of the Zagros orogenic belt of Iran: new data and interpretations. Tectonophysics. v. 229: 211-238.

2. Bates, R.L. and Jackson, J.A., 1980. Glossary of Geology. 2nd ed, American Geological Institute, Virginia, $751 \mathrm{pp}$.

3. Berberian, M., 1983. Continental deformation in the Iranian plateau. Geological Survey of Iran, Report No. 52. 625 pp.

4. Khalaf, F.I., \& Gharib, I.M., 1985. Roundness parameters of quartz grains of recent aeolian sand deposits in Kuwait. Sedimentary Geology. v. 45: 147-158

5. Pakzad, H., 2003. Sedimentary Facies Associations of the Lower Reaches of the Zayandeh River and the Gavkhoni Playa Lake Basin (Esfahan Province, Iran). Unpublished Ph.D. thesis. University of Clausthal, Germany

6. Pakzad, H. and Ajalloeian, R,. 2004. Geochemistry of the Gavkhoni playa lake brine. Carbonates and Evaporates, v. 19: 67-74

7. Stoecklin, J., 1968b. Structural history and tectonics of Iran; a review. America Association of Petroleum Geology Bulletin. v. 52(7), 1229-1285. 